\title{
Pendekatan Sulh dan Mediasi Sebagai Alternatif Terbaik Penyelesaian Sengketa Ekonomi Syariah
}

\author{
Abd. Rahman ${ }^{1 *}$, Faizatul Fitriyah $^{2)}$, Herman Efendi' ${ }^{3)}$, Adi Kusno ${ }^{4)}$ \\ ${ }^{1,2,3,4}$ Program Studi Ekonomi Syariah, Pascasarjana Institut Agama Islam Negeri Madura \\ *Email korespondensi: abdrahman0290@gmail.com
}

\begin{abstract}
This article will discuss efforts to resolve sharia economic disputes using the Sulh (peace) and Mediation approach to achieve justice. The type of research used is library research with a normative juridical approach that connects phenomina with the rule of law. In conventional business as well as in disputes, conflicts or disputes sometimes occur and cannot be avoided. Settlement of disputes in court takes a long time, costs a lot and the result is win-lose, causing a feeling of being unfair to one of the parties. For this reason, the method of Sulh (peace) and Mediation in resolving sharia economic disputes is the choice of sharia economic actors. Peace and Mediation can be developed using various models such as: negotiation and arbitration. This dispute resolution model is more acceptable to the community, because philosophically the values of sulh (peace) and Mediation (seeking joint solutions) that exist in Islamic law already exist intrinsically in the culture of Indonesian society which is more based on deliberation and harmony in social life.
\end{abstract}

Keywords: Disputes, Islamic economics, Sulh, Mediation, Justice.

Saran sitasi: Rahman, A., Fitriyah, F., Efendi, H., \& Kusno, A. (2021). Pendekatan Sulh dan Mediasi Sebagai Alternatif Terbaik Penyelesaian Sengketa Ekonomi Syariah. Jurnal Ilmiah Ekonomi Islam, 7(02), 961-969. doi:http://dx.doi.org/10.29040/jiei.v7i2.2488

DOI: http://dx.doi.org/10.29040/jiei.v7i2.2488

\section{PENDAHULUAN}

Semakin tumbuh pesatnya perbankan syariah dan Lembaga Keuangan Syariah (LKS) seperti pinjammeminjam, jual-beli, asuransi dan lain sebagainya berimplikasi pada semakin besar dan banyaknya sengketa antara pihak penyedia layanan dengan masyarakat yang dilayani. Dalam penyelesaian sengketa ekonomi syariah di Indonesia ada dua lembaga yang berwenang terhadap sengketa yang terjadi, yakni lembaga litigasi dan non litigasi. Badan litigasi (pengadilan) tersebut di Indonesia memiliki kelemahan-kelemahan dalam anggapan masyarakat, seperti dalam pelaksanaannya lebih banyak memutuskan dengan bernalar 'naif' ketimbang 'reasonable'. Terlebih, anggapan bahwa penyelesaian sengketa melalui pengadilan butuh waktu yang lumayan cukup panjang prosesnya dan mengeluarkan biaya yang cukup mahal.

Kajian-kajian terdahulu yang membahas tentang Penyelesaian Sengketa Ekonomi Syariah baik melalui litigasi ataupun non litigasi banyak dipublikasikan di jurnal-jurnal terakreditasi, terlebih kajian yang relevan dengan pembahasan artikel ini meskipun pembahasannya masih bersifat lebih general. Misalnya kajian tentang : Urgensitas Mediator Dalam Penyelesaian Sengketa Ekonomi Syariah Di Pengadilan Agama Purbalingga ; Model Penyelesaian Sengketa Ekonomi Syariah Yang Efektif Dikaitkan Dengan Kompetensi Di Peradilan Agama Dalam Rangka Pertumbuhan Ekonomi Nasional; Efektivitas Penerapan Prinsip-Prinsip Syariah Dalam Penyelesaian Sengketa Ekonomi Syariah di Badan Arbitrase Syariah Nasional (Basyarnas); Perbandingan Penyelesaian Sengketa Ekonomi Syariah Pada Masa Nabi Muhammad SAW. dan di Era Reformasi; Tinjauan Hukum Islam terhadap Musyawarah dalam Penyelesaian Sengketa Ekonomi Syariah. Namun dalam pembahasan artikel ini akan difokuskan dan lebih signifikan pada Pendekatan Sulh Dan Mediasi Sebagai Alternatif Terbaik Penyelesaian Sengketa Ekonomi Syariah yang kerap terjadi di masyarakat. 
Dalam menyelesaikan masalah fiqhiyyah, islam memiliki beberapa metode atau cara untuk menuntaskan suatu masalah baik dengan cara hukum islam itu sendiri atau dengan cara yang lebih mudah yaitu Sulh dan mediasi atau Perdamaian yang sangat menyatu dengan makna islam itu sendiri Maka tidak heran, didalam Islam tidak ada masalah yang tidak bisa diselesaikan secara damai dan adil selagi tidak menyangkut agama, keyakinan dan kemanusiaan.

Berdasarkan Pasal 1 ayat (1) Undang-Undang Nomor 39 Tahun 1999 Tentang Arbitrasi Dan Alternatif Penyelesaian Sengketa, Arbitrasi adalah cara penyelesaian suatu sengketa perdata di luar peradilan umum yang didasarkan pada perjanjian arbitrasi yang dibuat secara tertulis oleh para pihak yang bersengketa. Dengan keluarnya UU tersebut kiranya menjadi jawaban dan sebagai alternatif dalam hal penyelesaian sengketa syariah. Tegasnya, dalam al-Qur'an surat al-Hujurat: 9, yang menjelaskan tentang penyelesaian sengketa pada dasarnya bertujuan mencari keadilan, yakni sebagai berikut:

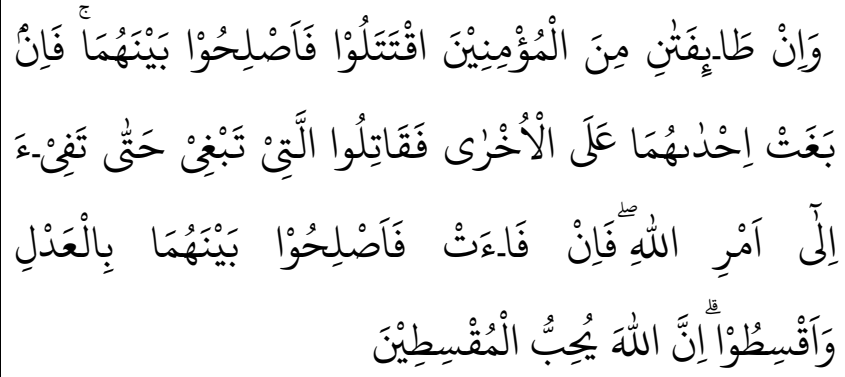

"Dan jika ada dua golongan dari orang-orang mukmin berperang maka damaikanlah antara keduanya. Jika salah satu dari kedua golongan itu berbuat aniaya terhadap golongan yang lain maka perangilah golongan yang berbuat aniaya itu sehingga golongan itu kembali, kepada perintah Allah; jika golongan itu telah kembali (kepada perintah Allah), maka damaikanlah antara keduanya dengan adil dan berlaku adillah. Sesungguhnya Allah menyukai orangorang yang berlaku adil".

Dengan berdasarkan ayat tersebut di atas bahwa penyelesaian sengketa melalui non litigasi, memang sudah terjadi pada masa rasulullah. Apalagi dalam adat masyarakat bahwa sebuah musyawarah sangat dijunjung tinggi dalam kehidupan bermasyarakat. Jadi,ketika sengketa ekonomi syariah harus melalui pengadilan, hal ini tentu akan sangat kurang tepat. Sebab apakah semua sengketa akan terselesaikan hanya melalui pengadilan (litigasi) yang dimana dalam prosesnya dibilang cukup lama, biaya mahal dan waktunya yang berbelit-belit.

\section{METODE PENELITIAN}

Sebuah penelitian diperlukan sebuah metode sebagai cara untuk mencapai tujuan. Adapun metode penelitian yang digunakan dalam artikel ini menggunakan metode kualitatif (library research) dan Pendekatan yang digunakan dalam artikel ini menggunakan beberapa pendekatan yaitu:

a. Pendekatan Normatif (pendekatan syar'i). Yaitu pendekatan yang mengakaji nilai-nilai syariat islam sesuai dengan yang berkaitan dengan masalah Artikel dengan cara mengkaji bahan pustaka atau data sekunder.

b. Pendekatan Yuridis (legal fomal atau berdasarkan Undang-undang yang berkaitan). Yaitu pendekatan dengan melihat Undang-undang yang sesuai atau data primer yang berkaitan dengan masalah yang diteliti oleh peneliti.

\section{HASIL DAN PEMBAHASAN}

\subsection{Hasil penelitian}

Pendekatan Sulh dan Mediasi ini memiliki karekateristik yang menunjukkan bahwa dalam pelakasanaan sulh dan mediasi dalam menyelesaikan masalah diperlukan sikap keterbukaan, kepercaayaan dan kejujuran para pihak dalam proses penyelesaian sengketa tersebut, disamping pula peran mediator dalam memberikan solusi terbaik amat mempengaruhi, guna menyelesaikan sengketa hukum yang terjadi secara adil, yaitu dengan mengimplementasikan konsep ishlah dalam setiap solusi yang ditawarkan.

Dari hasil penelitian ditemukan bahwa peran seorang pedamai dan mediator sangat mempengaruhi terjadinya kesepakatan damai dan saling menerima dari proses penyelesaian yang ditawarkan. Oleh karena itu harus bisa memposisikan diri sebagai seorang yang mempunyai sikap netralitas dalam memberiakan opsi penyelesaian. Paling tidak sikap dibawah ini harus dimiliki :

a. Tidak boleh melakukan penilaian tentang siapa yang benar dan siapa yang salah diantara para pihak yang sedang bersengketa.

b. Peran seorang pedamai dan mediator adalah pihak netral yang membantu para pihak dalam proses mediasi guna mencari berbagai macam solusi alternatif, tanpa menggunakan cara memutus dan atau memaksakan suatu penyelesaian tertentu. 
c. Seorang pedamai dan mediator memposisikan diri sebagai fasilitator yang memandu dan memperlancar serta mengarahkan jalannya perundingan yang berlangsung antara para pihak yang bersengketa.

\subsection{Pembahasan}

\section{Tahkim dalam Islam (Arbitrase)}

Mendefinisikan tahkin, kiranya penting diketahui terlebih dahulu bahwa arbitrasi (al-tahkim) atau perdamaian (sulh). Sulh dan mediasi sebenarnya mempunyai konsep yang sama, yaitu suatu proses penyelesaian sengketa dengan jalan damai, yakni para pihak yang bersangkutan duduk bersama mencari solusi akhir dari masalah yang mereka hadapi. Jadi bisa dikatakan bahwa sulh dan mediasi adalah suatu bentuk penyelesaian sengketa yang sama.

Secara bahasa, Sulh adalah memutus pertengkaran atau perselisihan. Dan dalam pengertian syari'at adalah suatu jenis akad untuk mengakhiri perlawanan antara dua orang yang berlawanan. Sedangkan, dalam kamus Al-munjid bahwa tahkim adalah mengangkat seseorang sebagai wasit atau juru damai. Sedangkan, Salam Madkur menyatakan dalam kitab Al-Qadha Fil Islam bahwa tahkim secara terminologis berarti mengangkat seseorang atau lebih sebagai wasit atau juru damai oleh dua orang atau lebih yang bersengketa guna menyelesaikan perkara yang mereka selisihkan secara damai. Adapun istilah sekarang tahkim dapat diterjemahkan sebagai arbitrasi, dan orang yang bertindak sebagai wasitnya disebut arbiter atau hakam.

Dalam perspektif Islam arbitrasi dapat disamakan dengan istilah tahkim. Tahkim berasal dari kata kerja hakama. Secara etimologi, kata itu berarti menjadikan seseorang sebagai pencegah suatu sengketa. Dalam literatur lain disebutkan bahwa tahkim adalah menyerahkan putusan pada seseorang dan menerima putusan itu dengan lapang. Abu Al-'Ainain Abdul Fatah Muhammad dalam bukunya yang berjudul $\mathrm{Al}$ Qadla Wa Al-Itsbat Fi Al Fiqih Al Islami menyebut definisi tahkim sebagai berikut:,Bersandarnya dua orang yang bertikai kepada seseorang yang mereka ridai keputusannya untuk menyelesaikan pertikaian mereka ${ }^{e}$. Abdul Karim Zaidan. Seorang pakar hukum Islam berkebangsaan Irak, dalam bukunya Nidzam AlQadla Fi Asy-Syari'at Al-Islamiyah menjelaskan bahwa yang dimaksud dengan tahkim adalah pengangkatan atau penunjukan secara suka rela dari dua orang yang bersengketa akan seseorang yang mereka percaya untuk menyelesaikan sengketa antara mereka.

\section{a. Sulh (damai) Sebagai Basis Penyelesaian Sengketa Ekonomi Syariah}

Perdamaian dalam syari'at Islam sangat dianjurkan. Apalagi, sudah seharusnya menjadi asas dalam hukum Islam acara perdata pengadilan (hakim) bahwa hakim wajib mendamaikan pihak yang berperkara. Sebab, dengan perdamaian akan terhindarlah kehancuran silaturrahim (hubungan kasih sayang) sekaligus permusuhan diantara pihak-pihak yang bersengketa akan dapat diakhiri. Disamping itu, sebenarnya penyelesaian sengketa ada beberapa model dalam tradisi Islam (model penyelesaian sengketa yakni jalur penyelesaian diluar peradilan yaitu musyawarah, as-sulh, tahkim, hisbah, dan jalur peradilan). Namun fokus kajian disini hanya pada model penyelesaian sengketa berbasis sulh (damai) dan mediasi, sebab dengan pertimbangan bahwa dalam QS. An-Nisa: 128, perdamaian itu lebih baik (dari pada perselisihan). Artikel ini menyajikan dasar hukum Sulh (damai) dari Nash dan Perundangundangan, lebih jelasnya sebagai berikut:

\section{Nash}

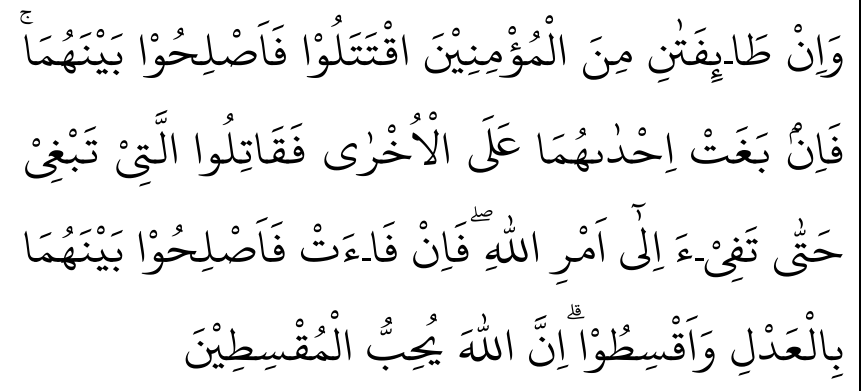

"Dan jika ada dua golongan dari orang-orang mukmin berperang maka damaikanlah antara keduanya. Jika salah satu dari kedua golongan itu berbuat aniaya terhadap golongan yang lain maka perangilah golongan yang berbuat aniaya itu sehingga golongan itu kembali, kepada perintah Allah; jika golongan itu telah kembali (kepada perintah Allah), maka damaikanlah antara keduanya dengan adil dan berlaku adillah. Sesungguhnya Allah menyukai orangorang yang berlaku adil”' (QS. Al-Hujurat: 9)

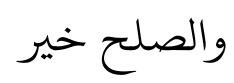

"Perdamaian itu lebih baik (dari pada perselisihan)” (QS. An Nisa': 128) 


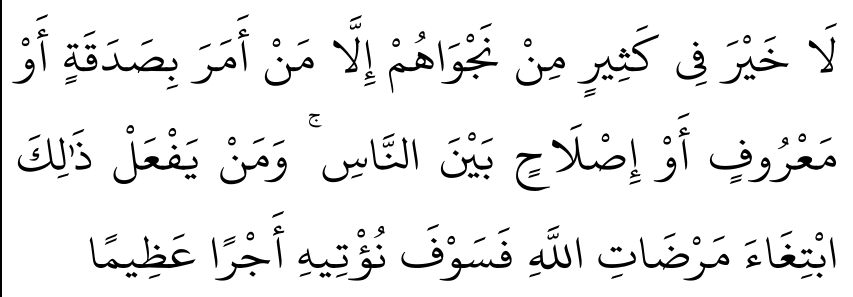

"Tidak ada kebaikan pada kebanyakan bisikan-bisikan mereka, kecuali bisikan-bisikan dari orang yang menyuruh (manusia) memberi sedekah, atau berbuat makruf, atau mengadakan perdamaian di antara manusia. dan barangsiapa yang berbuat demikian karena mencari keridaan Allah, Maka kelak Kami memberi kepadanya pahala yang besar. (QS. An-Nisa: 114)

Sumber kedua dari ajaran Islam, hadis Rasul juga menunjukan adanya peluang untuk menyelesaikan sengketa tanpa melalui badan peradilan pemerintah, dalam salah satu hadis yang diriwayatkan Tirmidzi dari Umar Bin Auf Al Muzani R A.

"Hasan bin 'Ali al-Khalal menceritakan kepada kami, Abu 'Amir al'Aqadiy menceritakan kepada kami, Katsir bin Abdillah bin Amru bin Auf alMuzanniy menceritakan kepada kami dari ayahnya, dari kakeknya bahwasannya Rasulullah SAW bersabda: Perjanjian antara orang-orang muslim itu boleh, kecuali perjanjian yang menghalalkan yang haram atau mengharamkan yang halal dan (muamalah) orangorang muslim itu berdasarkan syarat-syarat mereka kecuali syarat itu mengharamkan yang halal datau menghalalkan yang haram. Abu Isa berkata bahwa hadits ini hasan shahih."

Ijma ulama sebagai sumber hukum Islam yang ketiga telah memperkuat tentang adanya lembaga arbitrasi Islam untuk mengantisipasi persengketaan para pihak dalam berbagai aspek kehidupan. Penyelesaian sengketa setelah wafat rasullullah Saw. Banyak dilakukan pada masa sahabat dan ulama untuk menyelesaikan sengketa dengan cara mendamaikan para pihak melalui musyawarah dan konsensus diantara mereka sehingga menjadi yurisprudensi hukum Islam dalam beberapa kasus. Keberadaan ijma sahabat atau ulama sangat dihargai dan tidak ada yang menentangnya, karena tidak semua masalah sosial keagamaan tercantum dalam Al Qur'an dan As-sunah secara terinci. Bahkan Sayyidina Umar Ibnu Khatab pernah mengatakan bahwa : "Tolaklah permusuhan hingga mereka berdamai, karena pemutusan perkara melalui pengadilan akan mengembangkan kedengkian diantara mereka.

\section{Perundang-Undangan}

Penyelesaian sengketa diatur dalam UU. No. 30 Th. 1999, Arbitrasi dan APS, serta Perma No. 1 Th. 2016, mediasi dan pengadilan. Terlebih dalam peraturan perundang-undangan. Namun, Pasal 6 ayat (1) Undang-Undang Nomor 30 Tahun 1999 tentang Arbitrase dan Alternatif Penyelesaian Sengketa (,UU Arbitrase dan APS ) berbunyi: sengketa atau beda pendapat perdata dapat diselesaikan oleh para pihak melalui alternatif penyelesaian sengketa yang didasarkan pada itikad baik dengan mengesampingkan penyelesaian secara litigasi di Pengadilan Negeri.

Dalam cara arbitrasi (tahkim), para pihak yang bersengketa menunjuk perwakilan mereka masingmasing (hakam), untuk menyelesaikan sengketa mereka. Pada tanggal 21 Oktober 1993 MUI membentuk Badan Arbitrase Muamalat Indonesia (BAMUI). Kemudian pada tanggal 24 Desember 2003 berdiri Badan Arbitrase Syariah Nasional (basyarnas) sebagai ganti BAMUI, yang berwenang menyelesaikan sengketa perdata secara Islam. Namun berdasarkan Pasal 1851, 1855, 1858 KUH Per, penjelasan Pasal 3 UU No. 14/1970, serta UU No. 30/1999 tentang arbitrasi dan alternatif penyelesaian sengketa. Maka dari itu terbuka kemungkinan para pihak menyelesaikan sengketa dengan menggunakan lembaga selain pengadilan, seperti arbitrasi (altahkim) atau perdamaian (sulh). Sulh dan mediasi sebenarnya mempunyai konsep yang sama, yaitu suatu proses penyelesaian sengketa dengan jalan damai, yakni para pihak yang bersangkutan duduk bersama mencari solusi akhir dari masalah yang mereka hadapi. Jadi bisa dikatakan bahwa sulh dan mediasi adalah suatu bentuk penyelesaian sengketa yang sama.

\section{b. Mediasi}

Dari segi bahasa mediasi, berasal dari bahasa Inggris yaitu 'mediation' atau penengahan, yaitu penyelesaian sengketa yang melibatkan pihak ketiga sebagai penengah atau penyelesaian sengketa secara menengahi. Sedangkan secara etimologi, istilah mediasi berasal dari bahasa Latin, ,mediare yang berarti berada di tengah. Makna ini menunjuk pada peran yang ditampilkan pihak ketiga sebagai mediator harus berada pada posisi netral dan tidak memihak dalam menyelesaikan sengketa. Mediator harus mampu menjaga kepentingan para pihak yang bersengketa secara adil dan sama, sehingga 


\section{Jurnal Ilmiah Ekonomi Islam, 7(02), 2021, 965}

menumbuhkan kepercayaan (trust) dari para pihak yang bersengketa.

Pengertian mediasi secara lebih konkret dapat ditemukan dalam Peraturan Mahkamah Agung RI No. 01 Tahun 2008. Mediasi merupakan salah satu proses penyelesaian sengketa yang lebih cepat dan murah, serta dapat memberikan akses yang lebih besar kepada para pihak menemukan penyelesaian yang memuaskan dan memenuhi rasa keadilan. Pengintegrasian mediasi ke dalam proses beracara di pengadilan dapat menjadi salah satu instrumen efektif mengatasi masalah penumpukan perkara di pengadilan. Secara umum, mediasi adalah salah satu alternatif penyelesaian sengketa. Ada 2 jenis mediasi, yaitu di dalam pengadilan dan di luar pengadilan. Mediasi di luar pengadilan ditangani oleh mediator swasta, perorangan, maupun sebuah lembaga independen alternatif penyelesaian sengketa yang dikenal sebagai Pusat Mediasi Nasional (PMN). Mediasi yang berada di dalam pengadilan diatur oleh Peraturan Mahkamah Agung (PERMA) No. 1 Tahun 2008 yang mewajibkan ditempuhnya proses mediasi sebelum pemeriksaan pokok perkara perdata dengan mediator terdiri dari hakim-hakim Pengadilan Negeri tersebut yang tidak menangani perkaranya.

Penggunaan mediator, hakim dan penyelenggaraan mediasi di salah satu ruang pengadilan tingkat pertama tidak dikenakan biaya. Proses mediasi pada dasarnya tidak terbuka untuk umum, kecuali para pihak menghendaki lain.

Mediasi sebagai salah satu mekanisme penyelesaian sengketa alternative di luar pengadilan sudah lama dipakai dalam berbagai kasus-kasus bisnis, lingkungan hidup, perburuhan, pertanahan, perumahan, dan sebagainya yang merupakan perwujudan tuntutan masyarakat atas penyelesaian sengketa yang cepat, efektif, dan efisien. Disamping itu, mediasi dapat memperkuat dan memaksimalkan fungsi lembaga pengadian dalam penyelesaian sengketa di samping proses pengadilan yang bersifat memutus. Kemudian setelah dilakukan evaluasi terhadap pelaksanaan prosedur mediasi di pengadilan berdasarkan Peraturan Mahkamah Agung Republik Indonesia No 2 Tahun 2003 ternyata ditemukan beberapa permasalahan yang bersumber dari Peraturan Mahkamah Agung tersebut, sehingga Peraturan Mahkamah Agung tersebut perlu direvisi dengan maksud untuk lebih mendayagunakan mediasi yang terkait dengan proses berperkara di pengadilan.
Pada prinsipnya mediasi yaitu cara penyelesaian sengketa di luar pengadilan melalui perundingan yang melibatkan pihak ketiga yang bersifat netral (non intervensi) dan tidak berpihak (imparsial) serta diterima kehadirannya oleh pihak-pihak yang bersengketa. Pihak ketiga disebut mediator atau penengah, mempunyai tugas membantu pihak-pihak yang bersengketa dalam menyelesaikan masalahnya, tetapi tidak mempunyai kewenangan untuk mengambil keputusan. Namun hanya pada batasan perantara penyelesaian.

Di kalangan dunia bisnis, umumnya lebih mendayagunakan arbitrase sebagai alternatif penyelesaian sengketa bisnis yang terjadi diantara para pihak, daripada penyelesaiannya melalui lembaga litigasi atau peradilan. Hal ini terjadi karena saat sekarang ini ada suatu tendensi bahwa hampir di setiap kontrak dagang mencantumkan klausul penyelesaian sengketa melalui arbitrase, dimana arbitrase merupakan suatu lembaga penyelesaian sengketa yang sedang populer dan paling dianjurkan untuk digunakan dibandingkan dengan lembaga penyelesaian sengketa lainnya. Dalam menentukan cara penyelesaian sengketa tersebut, tentunya banyak pertimbangan yang mendasari para pelaku bisnis untuk memilih arbitrase sebagai upaya penyelesaian sengketa yang akan atau sedang dihadapi. Namun demikian, kadangkala pertimbangan para pelaku bisnis dalam memilih lembaga arbitrase sebagai alternative penyelesaian sengketa para pihak tidaklah sama, karena itu perlu diketahui dasar pertimbangan para pihak yang bersengketa dalam memilih arbitrase sebagai alternatif penyelesaian sengketa dalam kontrak dagang.

Secara umum dalam alinea keempat Penjelasan Umum UU No.30 Tahun 1999 tentang Arbitrase dan Alternatif Penyelesaian Sengketa dinyatakan dalam lembaga arbitrase mempunyai kelebihan dibandingkan dengan lembaga peradilan. Adapun kelebihan-kelebihan tersebut antara lain sebagai berikut:

1) Dijamin kerahasiaan sengketa para pihak.

2) Dapat dihindarkan kelambatan yang diakibatkan karena hal prosedur dan administrative.

3) Para pihak dapat memilih arbiter yang menurut keyakinannya mempunyai pengetahuan, pengalaman, serta latar belakang yang cukup mengenai masalah yang disengketakan, jujur dan adil. 


\section{Jurnal Ilmiah Ekonomi Islam, 7(02), 2021, 966}

4) Para pihak dapat menentukan pilihan hukum untuk menyelesaikan masalah serta proses dan tempat penyelenggaraan arbitrase.

5) Putusan arbiter merupakan putusan yang mengikat para pihak dan dengan melalui tata cara (prosedur) sederhana saja ataupun langsung dapat dilaksanakan.

Proses Mediasi di luar pengadilan (Non Litigasi) diatur dalam peraturan perundang-undangan. Namun dalam Pasal 6 ayat (1) Undang-Undang Nomor 30 Tahun 1999 tentang Arbitrase dan Alternatif Penyelesaian Sengketa berbunyi: "Sengketa atau beda pendapat perdata dapat diselesaikan oleh para pihak melalui alternatif penyelesaian sengketa yang didasarkan pada i'tikad baik dengan mengesampingkan penyelesaian secara litigasi di Pengadilan Negeri.". Secara konvensional, penyelesaian sengketa dalam dunia bisnis, seperti dalam perdagangan, perbankan, proyek pertambangan, minyak dan gas, energi, infrastruktur, dan sebagainya dilakukan melalui proses litigasi. Dalam proses litigasi menempatkan para pihak saling berlawanan satu sama lain, selain itu penyelesaian sengketa secara litigasi merupakan sarana akhir (ultimum remidium) setelah alternatif penyelesaian sengketa lain tidak membuahkan hasil (Winarta, 2012: 1-2). Hal serupa juga dikatakan oleh Rachmadi Usman bahwa selain melalui pengadilan (litigasi), penyelesaian sengketa juga dapat diselesaikan di luar pengadilan (non litigasi), yang lazim dinamakan denganAlternative Dispute Resolution (ADR) atau Alternatif Penyelesaian Sengketa.

Dari hal-hal di atas dapat kita ketahui bahwa litigasi itu adalah penyelesaian sengketa antara para pihak yang dilakukan di muka pengadilan. Menurut Pasal 1 angka 10 UU Arbitrase dan APS, Alternatif Penyelesaian Sengketa adalah lembaga penyelesaian sengketa atau beda pendapat melalui prosedur yang disepakati para pihak, yakni penyelesaian di luar pengadilan dengan cara konsultasi, negosiasi, mediasi, konsiliasi, atau penilaian ahli. Arbitrase sendiri adalah cara penyelesaian suatu sengketa perdata di luar peradilan umum yang didasarkan pada perjanjian arbitrase yang dibuat secara tertulis oleh para pihak yang bersengketa (Pasal 1 angka 1 UU Arbitrase dan APS). Frans Winarta dalam bukunya menguraikan pengertian masing-masing lembaga penyelesaian sengketa di atas sebagai berikut:

1) Konsultasi: suatu tindakan yang bersifat ,personal ${ }^{\circ}$ antara suatu pihak tertentu (klien) dengan pihak lain yang merupakan pihak konsultan, dimana pihak konsultan memberikan pendapatnya kepada klien sesuai dengan keperluan dan kebutuhan kliennya.

2) Negosiasi: suatu upaya penyelesaian sengketa para pihak tanpa melalui proses pengadilan dengan tujuan mencapai kesepakatan bersama atas dasar kerja sama yang lebih harmonis dan kreatif.

3) Mediasi: cara penyelesaian sengketa melalui proses perundingan untuk memperoleh kesepakatan para pihak dengan dibantu oleh mediator.

Akan tetapi dalam perkembangannya, ada juga bentuk penyelesaian di luar pengadilan yang ternyata menjadi salah satu proses dalam penyelesaian yang dilakukan di dalam pengadilan (litigasi). Kita ambil contoh mediasi. Dari pasal tersebut kita ketahui bahwa mediasi itu adalah penyelesaian di luar pengadilan, akan tetapi dalam perkembangannya, mediasi ada yang dilakukan di dalam pengadilan. Rachmadi Usman, mengatakan dengan diberlakukannya Peraturan Mahkamah Agung No. 1 Tahun 2008 tentang Prosedur Mediasi di Pengadilan, sebagai pengganti Peraturan Mahkamah Agung No. 2 Tahun 2003 tentang Prosedur Mediasi di Pengadilan, maka setiap perkara perdata tertentu yang akan diadili oleh hakim pengadilan dalam lingkungan peradilan umum dan peradilan agama diwajibkan terlebih dahulu untuk menempuh prosedur mediasi di pengadilan. Lebih lanjut, Rachmadi Usman, sebagaimana ia kutip dari naskah akademis yang dibuat oleh Pusat Penelitian dan Pengembangan Hukum dan Peradilan Mahkamah Agung Republik Indonesia, mengatakan bahwa sebenarnya lembaga mediasi bukanlah merupakan bagian dari lembaga litigasi, dimana pada mulanya lembaga mediasi berada di luar pengadilan. Namun sekarang ini lembaga mediasi sudah menyeberang memasuki wilayah pengadilan. Negara-negara maju pada umumnya antara lain Amerika, Jepang, Australia, Singapore mempunyai lembaga mediasi, baik yang berada di luar maupun di dalam pengadilan dengan berbagai istilah antara lain: Court Integrated Mediation, Court Annexed Mediation, Court Dispute Resolution, Court Connected ADR, Court Based ADR, dan lain-lain.

Kemudian dalam hal proses pengambilan keputusan, arbitrase memerlukan waktu sekitar 60 (enam puluh) hari sehingga prosesnya relatif cepat, terutama jika para pihak beritikad baik. Pertama; Dilakukan secara rahasia, Suatu keuntungan bagi 
dunia bisnis untuk menyerahkan suatu sengketa kepada badan/majelis arbitrase, yaitu bahwa pemeriksaan maupun pemutusan sengketa oleh suatu majelis arbitrase selalu dilakukan secara tertutup sehingga tidak ada publikasi dan para pihak terjaga kerahasiaannya. Sehingga pada siding pengadilan, menurut ketentuan peraturan perundang- perundangan yang berlaku, dilaksanakan dengan sifat terbuka untuk umum, begitu pula putusannya diucapkan dalam sidang terbuka.

Dalam mediasi, seorang mediator itu berperan membantu para pihak yang bersengketa dengan melakukan identifikasi persoalan yang dipersengketakan, mengembangkan pilihan, dan mempertimbangkan alternatif yang dapat ditawarkan kepada para pihak untuk mencapai kesepakatan. Mediator dalam menjalankan perannya hanya memiliki kewenangan untuk memberikan saran atau menentukan proses mediasi dalam mengupayakan penyelesaian sengketa. Mediator tidak memiliki kewenangan dan peran menentukan dalam kaitannya dengan isi persengketaan, ia hanya menjaga bagaimana proses mediasi dapat berjalan, sehingga menghasilkan kesepakatan (agreement) dari para pihak. Peranan penting yang harus dilakukan mediator antara lain adalah sebagai berikut: melakukan diagnosis konflik;

1) Mengidentifikasi masalah serta kepentingankepentingan kritis para pihak

2) Menyusun agenda

3) Memperlancar dan mengendalikan komunikasi

4) Mengajar para pihak dalam proses dan keterampilan tawar-menawar; dan

5) Membantu para pihak mengumpulkan informasi penting, dan menciptakan pilihan-pilihan untuk memudahkan penyelesaian problem.

6) Sebagai pihak netral yang melayani kedua belah pihak, mediator berperan melakukan interaksi dengan para pihak, baik secara bersama atau secara individu, dan membawa mereka pada tiga tahap sebagai berikut: a. memfokuskan pada upaya membuka komunikasi di antara para pihak.

7) Memanfaatkan komunikasi tersebut untuk menjembatani atau menciptakan saling pengertian di antara para pihak (berdasarkan persepsi mereka atas perselisihan tersebut dan kekuatan serta kelemahan masing-masing), dan

8) Memfokuskan pada munculnya penyelesaian sengketa.
Kemudian, Para pihak yang bersengketa nantinya dapat bebas memilih arbiter yang akan menyelesaikan persengketaan mereka. Jika dalam hal ini para pihak tidak bersepakat dalam memilih arbiter, maka penunjukan arbiter akan menjadi kewenangan pengadilan negeri, sebagaimana disebutkan dalam Pasal 13 (1) UU No.30 Tahun 1999, 'Apabila tidak tercapai kesepakatan mengenai pemilihan arbiter atau tidak ada ketentuan mengenai pengangkatan arbiter, ketua pengadilan negeri dapat menunjuk arbiter atau majelis arbitrase'. Disamping adanya kemungkinan penunjukan arbiter yang dilakukan oleh hakim, penunjukan arbiter juga bisa dilakukan oleh badan arbitrase tertentu. Badan arbitrase mana yang akan berwenang menentukannya tergantung pada kontrak arbitrasenya.

Putusan arbitrase pada umumnya dianggap final dan binding (tidak ada upaya untuk banding). Namun apabila hukum yang berlaku dalam yurisdiksi yang bersangkutan menetapkan pelaksanaan putusan arbitrase melalui pengadilan, maka pengadilan harus mengesahkannya dan tidak berhak meninjau kembali persoalan (materi) dari putusan tersebut. Biaya arbitrase biasanya terdiri dari biaya pendaftaran, biaya administrasi dan biaya arbiter yang sudah ditentukan tarifnya. Prosedur arbitrase dibuat sesederhana mungkin, tidak terlalu formal. Di samping itu para arbiter adalah para ahli dan praktisi di bidang atau pokok yang dipersengketakan sehingga diharapkan akan mampu memberikan putusan yang cepat dan objektif. Hal ini tentunya menghemat biaya jika dibandingkan dengan melalui pengadilan. Lalu, dalam hal keputusan arbitrase umumnya lebih mudah dilaksanakan daripada putusan pengadilan. Hal ini disebabkan karena putusan arbitrase bersifat final dan binding, yang tentunya dilandasi dengan itikad baik para pihak. Pelaksanaan putusan arbitrase ini tergantung para peraturan arbitrase yang berlaku dalam yurisdiksi dimana para pihak meminta untuk melaksanakan putusan arbitrase. Keputusan arbitrase mungkin akan lebih cepat dilaksanakan daripada melaksanakan putusan pengadilan. Hal ini disebabkan putusan arbitrase itu dianggap final dan tidak dapat diajukan banding kecuali ada alasan atau dasar yang khusus.

\section{KESIMPULAN}

Penyelesaian sengketa ekonomi syariah non litigasi yang berbasis sulh (damai) ataupun mediasi, merupakan pilihan yang tepat dan alternatif terbaik 
dalam menyelesaikan masalah sengketa yang terjadi di kehidupan bermasyarakat khususnya dalam bidang ekonomi syariah. Apalagi, pada prinsipnya ekonomi syariah, sangat menjunjung tinggi asas keadilan dan kemaslahatan umat. Penyelesaian dengan berbasis sulh (damai) dalam Islam sangat dianjurkan sebagaimana QS. An-Nisa : 128. Istilah sulh dan mediasi ada yang mengatakan bahwa keduanya sama dalam hal tujuannya, yakni mencari solusi dengan cara menghadirkan pihak ketiga (netral) sebagai pemutus perkara dengan memandang kepada tujuan baik bagi keduanya atas sengketa yang terjadi. Dalam prosesnya tidak membutuhkan waktu yang lama (60 hari) dari awal pelaporan kasus sampai hasil putusan. Hemat biaya dan putusan dari arbitrasi atau sulh itu bersifat final dan binding (tidak ada upaya untuk banding).

Adapun mekanisme sulh ataupun mediasi itu dengan cara bermusyawarah terlebih dahulu sesuai dengan waktu yang telah di agendakan oleh mediator atau arbiter dengan kedua belah pihak yang ada sengketa. Terlebih musyawarah sudah menjadi tradisi di Indonesia yang secara filosofis jawa bahwa sebuah musyawarah (rembugan; red. Jawa) akan menghasilkan keputusan yang terbaik dan mengutamakan keadilan. Jadi, dengan penyelesaian sengketa berbasis sulh (damai) dan mediasi yang non litigasi akan membantu tugas dan wewenang lembaga peradilan, tentunya dengan tetap membawa ruh dan basis tujuan hukum peradilan Islam yakni keadilan.

\section{UCAPAN TERIMA KASIH}

Penulis mengucapkan terima kasih kepada semua pihak yang telah memberikan motivasi dan doa sehingga penelitian ini dapat terselesaikan dengan baik. Teruntuk kepada orang tua dan orang-orang yang peduli pada proses penyelesaian penelitian ini baik yang berkontribusi langsung atau tidak.

\section{REFERENSI}

Triana, Nita, Urgensitas Mediator Dalam Penyelesaian Sengketa Ekonomi Syariah Di Pengadilan Agama Purbalingga.

https://garuda.ristekbrin.go.id/documents/detail/1402 $\underline{784}$

B, Renny Supriyatni, Fariana, Andi, Model Penyelesaian Sengketa Ekonomi Syariah Yang Efektif Dikaitkan Dengan Kompetensi Di Peradilan Agama Dalam Rangka Pertumbuhan Ekonomi Nasional. https://garuda.ristekbrin.go.id/documents/detail/5498 $\underline{50}$

Pramudya, Kelik, Strategi Pengembangan Ekonomi Syariah Melalui Penguatan Fungsi Pengadilan Agama Dalam Penyelesaian Sengketa

https://garuda.ristekbrin.go.id/documents/detail/6122 $\underline{29}$

Priadi, Eko, Munthe, Mhd Erwin, Keabsahan Putusan Badan Arbitrase Syariah Nasional Dalam Penyelesaian Sengketa Ekonomi Syariah Di Indonesia.

https://garuda.ristekbrin.go.id/documents/detail/ $\underline{1878670}$

Zaidah Nur Rosidah, Layyin Mahfiana, Efektivitas Penerapan Prinsip-Prinsip Syariah Dalam Penyelesaian Sengketa Ekonomi Syariah di Badan Arbitrase Syariah Nasional (Basyarnas).

https://moraref.kemenag.go.id/documents/article/988 10827380884664

Modal Intelektual Sebagai Alternatif Penyelesaian

Sengketa Ekonomi Pada Bank Syariah Mandiri

Kcp Ponorogo

https://moraref.kemenag.go.id/documents/article/988 $\underline{93412974992240}$

Nurul Umam, Erie Hariyanto, Perbandingan Penyelesaian Sengketa Ekonomi Syariah Pada Masa Nabi Muhammad SAW. dan di Era Reformasi.

https://moraref.kemenag.go.id/documents/article 198893412974986974

Asrizal, Asrizal, Pilihan Penyelesaian Sengketa Ekonomi Syariah Bagi Masyarakat: Antara Litigasi Dan Non-Litigasi.

https://garuda.ristekbrin.go.id/documents/detail/8752 $\underline{18}$

Ilyas, Musyfikah, Tinjauan Hukum Islam terhadap Musyawarah dalam Penyelesaian Sengketa Ekonomi Syariah.

https://garuda.ristekbrin.go.id/documents/detail/8935 $\underline{18}$

Yasin, Mohamad Nur, Reformasi Hukum Ekonomi Islam Di Indonesia Studi Klausula Penyelesaian Sengketa Ekonomi Syariah Dalam Fatwa Dewan Syariah Nasional 2000-2017. https://garuda.ristekbrin.go.id/documents/detail/ $\underline{936575}$

Muhammad, Hasanuddin, Efektifitas Dan Efisiensi Penyelesaian Sengketa Ekonomi Syariah Di Peradilan Agama. 
Jurnal Ilmiah Ekonomi Islam, 7(02), 2021, 969

https://garuda.ristekbrin.go.id/documents/detail/1738 $\underline{548}$

Hadiyanto, Redi, Penyelesaian Sengketa Ekonomi Syariah Menjadi Kewenangan Pengadilan Agama Pasca Putusan Mahkamah Konstitusi Nom0r 93/Puu-X/201. https://garuda.ristekbrin.go.id/documents/detail/ $\underline{1513072}$

Suhartono, Suhartono, Urgensitas Penguatan Kompetensi Penyelesaian Sengketa Ekonomi Syariah Di Pengadilan Agama Dalam Mengawal Pertumbuhan Industri Keuangan Syariah Di Indonesia.

https://garuda.ristekbrin.go.id/documents/detail/5446 $\underline{67}$

Rahmawati, Naili, Kesiapan Hakim dalam Penyelesaian Sengketa Ekonomi Syariah Pasca Keluarnya PERMA No. 14 Tahun 2016.

https://garuda.ristekbrin.go.id/documents/detail/9294 $\underline{87}$

Abbas, Syahrizal, 2011. Mediasi Dalam Hukum Syahriah, Hukum Adat, dan Hukum Nasional, Jakarta: Kencana.

As-Shiddiqi, Hasby, 2001. Peradilan dan Hukum Acara Islam., Semarang: Pustaka Rizki Putra.

Effendi M. Zein, Satria, 1994. Arbitrasi Dalam Syariat Islam, atau lihat Abdul Rahman Saleh, Arbitrasi lslam Di Indonesia, Jakarata: Badan Arbitrasi Muamalat Indonesia.
Husni, M, Arbitrase Sebagai Alternatif Penyelesaiansengketa Bisnis Di Luar Pengadilan', Jurnal EQUALITY, Vol. 13 No. 1 Februari 2008.

J. Stit, Allan, 2004. Mediation: A Practical Guide, London: Routledge Cavendish.

Kamus al-Munjid

Lubis, Suhrawardi, 2000. Hukum ekonomi Islam, Jakarta: Sinar grafindo. Peraturan Mahkamah Agung RI No.1 Tahun 2008

Rosyadi, Rahmat, 2002. Arbitrasi Dalam Perspektif Islam Dan Hukum Positif, Bandung: Citra Aditya Bhakti.

Sabiq, Sayyid, 1998. Fikih Sunnah 13, Bandung : AlMa'arif.

Sutiyoso, Bambang, 2008. Hukum Arbitrase dan Alternatif Penyelesaian Sengketa, Yogyakarta: Gama Media.

Usman, Rachmadi, 2012. Mediasi di Pengadilan, Jakarta: Sinar Grafika. Winarta, Hendra, 2012. Hukum Penyelesaian Sengketa, Jakarta: Sinar Grafika.

Soemartono, Gatot, 2006. Arbitrase danMediasi di Indonesia, Jakarta: Gramedia Pustaka Utama. 